\title{
“'Her Chinese Attended to Almost Everything': Relationships of Power in the Hackett Medical College for Women, Guangzhou, China, 1901-1915"
}

\author{
Connie Shemo \\ Plattsburgh State University \\ shemoca@plattsburgh.edu
}

\begin{abstract}
This essay uses a 1915 crisis at the American Presbyterian Hackett Medical College for Women in Guangzhou, China as a lens to explore the level of control Chinese women, who were known as "assistants," exercised at the school. Official literature of the Hackett portrays the American woman missionary physician Dr. Mary Fulton as controlling the college, but in fact its Chinese women graduates largely ran the institution for some years before 1915. Challenging images of American women missionary physicians either as heroines or imperialists, this article describes instead how Chinese women shaped the institution. Placing the Hackett into the broader context of American Presbyterian medical education for Chinese women since 1879, it argues that rather than only interpreting and adapting missionary ideologies, many of the Chinese women medical students in Guangzhou brought their own conceptions of women practicing medicine. In the case of medical education for women in Guangzhou before 1915, American missionaries were partially responding to Chinese traditions and demands. Ultimately, this essay presents a more complex view of cultural transfer in the women's foreign mission movement of this period.
\end{abstract}

\section{Keywords}

Hackett Medical College for Women - Rockefeller Foundation - China Medical Board Western medicine in China - medical education for women - American women missionaries - American women physicians - Chinese women physicians Guangzhou - cultural transfer - imperialism

In 1913, Martha Hackett, a physician recently graduated from Rush Medical College in Chicago, along with her friend Harriet Allyn, a biologist who had 
graduated from the University of Chicago, arrived in Guangzhou, China to help run the Hackett Woman's Medical College and women's hospital of the American Presbyterian mission in Guangzhou. As her name suggests, Dr. Martha Hackett had a special relationship to the Hackett medical school. Her father E.A. Hackett had made a generous donation to the medical college for women in 1901, two years after Dr. Mary Fulton had founded the school in 1899. As was typical missionary practice, Fulton, the American missionary physician in charge, had named the medical school for its American benefactor.

In the late $19^{\text {th }}$ and early $20^{\text {th }}$ Centuries, Fulton was one of the most important advocates of medical education for Chinese women within China. The Presbyterian South China Medical College had begun accepting a few Chinese women students in 1879, five years before Fulton's arrival in 1884. While at first Fulton was not involved in teaching at the medical school, she became more active in this regard in the 189os. She founded the medical school for Chinese women after a dispute between two male missionary physicians in 1899 had split the South China Medical College and left the five Chinese women students then enrolled with no way to finish their education. While there were some informal attempts of individual women missionaries to train Chinese women physicians, the only other formal Western style medical education for Chinese women in the $19^{\text {th }}$ Century was in the Southern Methodist medical school in Suzhou, which educated far fewer Chinese women than the Hackett. The North China Union Medical College for Women, the first medical school for Chinese women in northern China, commenced operations in $1908 .^{1}$

In the process of fundraising for the school she founded, Fulton had formed a close relationship with the Hackett family, visiting it when she was on furlough in the United States and describing in horrific detail the medical distress of Chinese women. These stories had inspired Martha Hackett to seek a medical education with the express purpose of helping to ameliorate the sufferings of Chinese women. Hackett had grown up on Fulton's descriptions of restoring sight to the blind, removing tumors, and generally "alleviating the miseries of the Chinese, so often the consequence of ignorance of the fundamentals of the medical art." Fulton emphasized that the Hackett Medical College "should appeal to every heart that desires to mitigate human agony" and "elevate woman."2

1 The most thorough and most accessible source in English for statistics and dates on medical institutions in China during this period is still Wong Chimin and Wu Lien-teh, History of Chinese Medicine being a Chronicle of Medical Happenings in China from Ancient Times to the Present Period (Shanghai: National Quarantine Service, 1936). For medical education for women during the period under discussion, see pages $482,497,481,522,527,532,544,612$.

2 Mary Hannah Fulton, Inasmuch: Extracts from Letters, Journals, Papers, Etc. (West Medford, MA: Central Committee on the United Study for Foreign Missions, 1915), 87, 97; Mary 
However, once they had arrived in China, Martha Hackett and Harriet Allyn encountered a very different institution than they thought they had been led to expect. In 1915, in a series of anguished letters to the Presbyterian Board, they laid out these differences. Most prominent in their complaints was that the Hackett Medical School was not equipped to turn out "doctors" as they understood the term. The only requirement for admission was literacy in Chinese. It was, they reported, virtually impossible to equip these students with the understanding of Western science that recently had become fundamental to the medical profession in the United States. They also addressed another issue. For all practical purposes, Chinese women who had graduated from the Hackett and gone on to teach and practice medicine in the institution (as opposed to going into private practice, as did the majority of graduates) ran the medical school and hospital. While official mission literature referred to these women as "assistants," in fact they exercised significant control in the medical school and hospital. Martha Hackett and Harriet Allyn found them unreceptive to the changes they believed the Hackett needed to make to turn the institution into a medical school as they understood the term. Rather than suffering Chinese women waiting for their healing touch or eager for their instruction, they found an entrenched power structure determined to keep the institution as it was.

A number of scholars have discussed the history of the Hackett Medical in essays and in book chapters, both in Chinese and English. The earliest scholarship focused on the perspective of the American women missionary physicians, such as Fulton, Hackett, and Allyn, involved in developing the Hackett. More recent scholarship includes greater information on the Chinese women graduates of the Hackett. ${ }^{3}$ Particularly notable is Xu Guangxiu's chapter on the Hackett in his book on American medical work in Guangzhou, in which

H. Fulton, M.D.,"Hackett Medical College for Women, Canton," China Medical Journal 23, no. 5 (September 1909): 324-29, 326 .

3 The most through treatments in English are Sara Tucker, "A Mission for Change in China: The Hackett's Women's Medical Center of Canton, China, 1900-1930," in Women's Work for Women: Missionaries and Social Change in Asia, Leslie Fleming, ed. (Boulder, co: Westview Press, 1985), 137-57; Guangqiu Xu, American Doctors in Canton: Modernization in China, 1835-1935 (New Brunswick, NJ: Transaction Publishers, 2011), Chapter 3; Motoe Sasaki-Gayle, "Entangled with Empire: American Women and the Creation of the 'New Woman' in China," unpublished Ph.D. dissertation, Johns Hopkins University, Baltimore, MD, 2008. In Chinese, see Peng Shumin, "Zhongguo jidujiao jindai nuzi gaodeng yixue jiaoyu de chuanli: Fu Mali Yisheng ji Xiage Nuzi Yixueyuan" ["The Chinese Christian Church and the Establishment of Medical Education for Modern Chinese Women: Fu Mali (Mary Fulton) and the Hackett Medical College for Women"], in Jidujiao yu Zhongguo shehui wenhua [The Christian Church and Chinese Society and Culture], Wu Ziming and Wu Xiaoxin, eds. (Hong Kong: Hong Kong 
he explores "the social and political role of the women doctors educated by Americans and their impact on the modern women's rights movements." $\mathrm{Xu}$ combines archival research in the United States and Guangzhou with interviews with people who knew some of the most prominent graduates of the Hackett, offering the fullest picture to date of the medical and political activities of these women.

While $\mathrm{Xu}$ concentrates on the later careers of Hackett graduates, the focus here is on the complex power structure in the Hackett in the period before 1915, looking especially at the extent of the influence of Chinese women physicians who worked at the school. The official literature of the Hackett portrays Mary Fulton as completely in control, with Chinese women acting as "assistants." Discussion of the importance of Chinese women in running the Hackett surfaces only in private letters between Martha Hackett and Harriet Allyn and the Board during the crisis of 1915 to 1916, and members of the First and Second Rockefeller Commission that the Rockefeller Foundation sent to China to survey the medical landscape there in 1914 and 1915, respectively, in preparation for the creation of the China Medical Board and the establishment of Peking Union Medical College. For Rockefeller Commission members and Hackett and Allyn alike, the discussion of the influence of Chinese women physicians at the Hackett Medical College occurred in the context of a wider critique of the institution as insufficiently committed to the practice of "modern" scientific medicine. Critics of an organization can sometimes offer insight that official, published accounts or even alumni reflections do not.

A focus on the power of Chinese women physicians in running the Hackett is part of a broader argument about American missionary medical education for Chinese women in Guangzhou. Xu and other scholars generally have portrayed missionary medical education for Chinese women as an idea originating in the United States and exported to China. ${ }^{5}$ In contrast, this essay argues that the American Presbyterian commitment to providing medical education for Chinese women developed because of Chinese requests, and was part of a larger tradition in Guangzhou of Chinese women making money from medical work. American missionary physicians taught new techniques and provided

University Institute for the Study of Religion and the Center for the Study of Religion in Chinese Society, 2008), 319-54.

$4 \mathrm{Xu}$, American Doctors in Canton, p. 131.

5 Ibid., Chapter 4; Tucker, "A Mission for Change in China;" Li Chuanbin, Tiaoyue techuan zhidu xia de yiniao shiye: Jidujiao zai Hua yiliao shiye yanjiu 1835-1937 [Healing Under Treaty Port Privileges: A Study of Christian Medical Work in China, 1895-1937] (Changsha: Hunan Renmin Chubanshe, 2010), 293-95. 
the title of "physician," thus offering more respectability and potentially more income-earning potential for Chinese women who healed professionally. They also offered medical training to a broader range of Chinese women. As Chinese reformers and government officials in the early $20^{\text {th }}$ Century came to view improving the health of Chinese women and children as central to the creation of a strong China able to resist imperialism, the Hackett also offered Chinese women the chance to express their patriotism. Prior to the crisis in 1915, however, American Presbyterians provided expanded opportunities for women medical practitioners in Guangzhou rather than introducing an entirely new profession to women.

Viewing the Hackett in this light complicates portrayals of American women missionary physicians on one hand as heroines, and on the other, as imperialists. This focus on the importance of Chinese traditions of female healers in beginning medical education for Chinese women in Guangzhou does not preclude an understanding of the complex ways in which the history of the Hackett was interwoven with the history of Western - and specifically U.s.imperialism in China. Much of the writing on Mary Fulton and other women missionary physicians during this time fits well into what Antoinette Burton has termed the "white woman's burden" in her study of the ways in which $19^{\text {th }}$ and early $20^{\text {th }}$ Century British women used images of oppressed women in British colonies, most notably India, to argue for more access to education and public life. Despite the limited formal empire of the United States during this period, a number of scholars have argued for a similar dynamic in women's rights movements in the United States. Because Western male physicians had limited access to upper-class Chinese women, medical missions also provided an important justification for medical education for women in the United States, at the time a controversial venture. Ruth Rogaski has emphasized the "violence and racism" of imperialism underlying notions of Western hygiene and other medical concepts in China, especially in the wake of the Boxer Uprising. ${ }^{6}$ Discussions of women dying and suffering because they could

6 Antoinette Burton, Burdens of History: British Feminists, Indian Women, and Imperial Culture, 1865-1915 (Chapel Hill: University of North Carolina Press, 1994); Louise Newman, White Woman's Rights: The Racial Origins of Feminism in the United States (New York: Oxford University Press, 1999); Kristin Gleeson, "Healers Abroad: Presbyterian Women Physicians in the Foreign Mission Field," unpublished Ph.D. dissertation, Temple University, Philadelphia, PA, 1996; Lisa Joy Pruitt, “A Looking Glass for Ladies”: American Protestant Women and the Orient in the Nineteenth Century (Macon, GA: Mercer University Press, 2005), Chapter 6; Connie Shemo, The Chinese Medical Ministries of Kang Cheng and Shi Meiyu: On a Cross-cultural Frontier of Gender, Race, and Nation (Bethlehem, PA: Lehigh University Press, 2011), Chapter 1; Sarah Pripas-Kapit, "Piety, Professionalism, and Power: Chinese Protestant Missionary Physicians 
not find treatment in the medical traditions already existing in their countries provided an especially powerful condemnation of "heathen" cultures and an urgent need for intervention.

However, an exclusive focus on the imperialism inherent in the discourses of Western women missionary physicians such as Fulton can reproduce inadvertently the contrast between empowered Western (read "white") women and oppressed Chinese women that was central to imperialist discourses. Even if one condemns American women as imperialists, it was still the imperialist images of suffering "heathen" women that motivated them to seek actively the rights of Chinese women. This essay now revisits this activism with the goal of contesting the images of progressive (if imperialist) American women and tradition-bound Chinese women during this time that continue to dominate popular culture and even much scholarship in both China and the United States. ${ }^{7}$

American medical missionary work had a long history in Guangzhou, known in the West as Canton. Prior to 1842, when the Treaty of Nanjing ending the Opium War "opened" four other treaty ports to Western missionaries, Guangzhou was the only place in China where Westerners could reside, and then only temporarily. They also could not evangelize openly. As a result, when the American missionary Peter Parker went to China in 1835, he first trained as a physician so he could open a medical center. He almost immediately began to train Chinese as "assistants," some of whom achieved prominence in their own right. While Parker originally had been a missionary under the American Board of Commissioners for Foreign Missions (ABCFM), he left this mission board in 1847 because of conflicts over the time he devoted to medical work and

and Imperial Affiliations Between Women in the Early Twentieth Century," Gender and History 27, no. 2 (August 2015), 349-73; Ruth Rogaski, Hygienic Modernity: Meanings of Health and Disease in Treaty Port China (Berkley: University of California Press, 2004), 254. For more on the practice of American women missionaries in China and the philosophy of the American women's foreign mission movement, see Jane Hunter, Gospel of Gentility: American Women Missionaries in Turn-of-the-Century China (New Haven, Ст: Yale University Press, 1984); Dana Robert, American Women in Mission: A Social History of Their Thought and Practice (Macon, GA: Mercer University Press, 1997).

7 Chandra Talpade Mohanty has presented a classic critique of this portrayal of "third world women." Chandra Talpade Mohanty, "Under Western Eyes: Feminist Scholarship and Colonial Discourses," in Third World Women and the Politics of Feminism, Chandra Talpade Mohanty, Ann Russo, and Lourdes Torres, eds. (Bloomington: Indiana University Press, 1991), $5^{1-78}$. For a more recent discussion focusing more specifically on the long-term impact of missionary discourses on the perception of non-western women in the United States, see Pruitt, “A Looking Glass for Ladies," pp. 177-85. 
diplomacy. Dr. John Kerr, of the American Presbyterian Board, took charge of the hospital in 1855 , and thereafter, Presbyterian missionaries ran the hospital. ${ }^{8}$

By 1866, the desultory training of assistants had coalesced into the "South China Medical College," which granted the title of "physician" to its graduates. In contrast to Europe, there was during this time no state-mandated definition of the education required for a person to earn the title of "physician" in either the United States or China. In the United States, there were medical schools of competing medical traditions, with varying lengths of study - some as short as six months - any of which could grant its graduates the designation of physician. Likewise, each school determined its own prerequisites. While medical missionaries as a rule came from "regular" medical schools with courses of study of three to four years, before the 1890 os no medical school in the United States gave the kind of grounding in the emerging "scientific medicine" that existed in the government-run medical schools in countries such as France, Switzerland, and Germany. Physicians in the United States who wanted more advanced medical education would travel to Europe for additional study. ${ }^{9}$

In $19^{\text {th }}$ Century China, there were a wide variety of schools of medical thought, but no formal system of medical education. In late imperial China, the most elite physicians were the scholar-physicians (ruyi), who belonged to the class of scholars and gained their medical knowledge from extensive study of the texts. Competing, but also in part overlapping, were hereditary physicians (shiyi) whose medical knowledge had passed down to them through prior generations. Much lower in social status than either ruyi or shiyi were a host of other healers, such as itinerant folk doctors. However, law mandated none of these distinctions. In late imperial China, the Chinese government did

8 Wong and Wu, History of Chinese Medicine being a Chronicle of Medical Happenings in China from Ancient Times to the Present Period, pp. 318-20; Sara Tucker, "The Canton Hospital and Medicine in Nineteenth Century China, $1835^{-1900, " ~ u n p u b l i s h e d ~ P h . D . ~ d i s s e r t a t i o n, ~ I n d i a n a ~}$ University, Bloomington, IN, 1982, 138-41; Edward V. Gulick, Peter Parker and the Opening of China. (Cambridge, MA: Harvard University Press, 1973); William Cadbury and Mary Hoxie Jones, At the Point of a Lancet: One Hundred Years of the Canton Hospital, 1835-1935 (Shanghai: Kelly and Walsh, Limited, 1935), 33-53, 101; Harriet Noyes, History of the South China Mission of the American Presbyterian Church, 1845-1920 (Shanghai: Presbyterian Press, 1927), 48.

9 Cadbury and Jones, At the Point of a Lancet, pp. 175-77; Tucker, "The Canton Hospital and Medicine in Nineteenth Century China, $1835^{-1900, " ~ p p . ~ 151-55 . ~ F o r ~ a ~ g o o d ~ s o u r c e ~ o n ~ t h e ~}$ transformations in American medicine, see Paul Starr, The Social Transformation of American Medicine (New York: Basic Books, 1982). Peter Buck connects these changes to the China mission field. Peter Buck, American Science and Modern China, 1876-1936 (Cambridge, MA: Cambridge University Press, 1980). 
not stop any person from taking the title of "physician" formally. ${ }^{10}$ There was nothing, therefore, in the laws of either the United States or China to prevent American Presbyterians, or any other missionaries, from beginning a medical school and calling its graduates "physicians." Relatedly, there were no laws that reserved the title of "physician" for men. In 1879, three Chinese young women who had trained at the True Light Seminary, the Presbyterian mission school for girls, asked for admission to the medical school. This request came in the absence of any American women physicians to act as role models. The missionaries debated this request extensively. Finding that "responsible Chinese" in the mission approved, they admitted the women to the school. Kerr, who was in charge of the medical school, encouraged the women and promised them "the same advantages and instruction as the young men received."11

In her memoir, the head of the True Light Seminary, Harriet Noyes, emphasized that studying medicine "was an entirely new idea for Chinese women." Yet earlier in this same memoir, Noyes presented two examples of Chinese women practicing medicine. She recounted that soon after her arrival in China in 1868, a Bible woman took her to see a "boarding school for girls said to have been established 60 years before." The principal of the school was a woman who "gave much of her own time to the practice of medicine, from which she received a good income." In a discussion of the first girls to enter the True Light Seminary in 1873 , Noyes noted that the father of the first two students "had been employed in the Canton Hospital for many years, and had acquired a little knowledge of the healing art, which he in turn imparted to his daughters." The older girl married soon after leaving school "and in addition to the care of her family has acquired some local reputation as a doctor." While Noyes reported this last case with relative equanimity, in fact medical missionaries

10 Yuan-ling Chao, Medicine and Society in Late Imperial China: A Study of Physicians in Suzhou, 1600-1850 (New York: Peter Lang, 2009); Volker Scheid, Currents of Tradition in Chinese Medicine, 1626-2006 (Seattle, wA: Eastland Press, 2007); Bridie Andrews, The Making of Chinese Medicine, 1850-196o (Vancouver, Canada: University of British Columbia Press, 2014), Chapter 1. While the Chinese government never had regulated the title of "physician" strictly, in the Song (960-1279 C.E.) and Yuan (1271-1368 C.E.) dynasties there had been more imperial involvement in training physicians. During the Qing Dynasty (1636-1912 C.E.), the government withdrew from any regulatory role. See Angela Ki-che Leung, "Organized Medicine in Ming-Qing China: State and Private Institutions in MingQing China," Late Imperial China 8, no. 1 (June 1987): 137-66.

11 Harriet Newell Noyes, A Light in the Land of Sinim - Forty Five Years in the True Light Seminary (New York and London: Fleming H. Revell Company, 1919), 85-86. See also Tucker, "The Canton Hospital and Medicine in Nineteenth Century China, 1835-1900," pp. 209-10; $\mathrm{Xu}$, American Doctors in Canton, pp. 136-38. 
frequently railed against hospital workers meant to do menial tasks who picked up enough understanding of medical techniques the missionary physicians used to feel comfortable leaving the employ of the hospital and setting up their own medical practices. ${ }^{12}$ There were, however, no laws in China to stop this practice, or even, as in this case, prevent former hospital employees from imparting the knowledge they had received to their children so they in turn could present themselves as "doctors."

Noyes's recollections of female doctors fit well with recent scholarship on Chinese women healers. Yi-li Wu observes that "female healers of all kinds," including female physicians, were a "standard part of the medical landscape" in late imperial China. Female healers who had the title of "physician" were usually from families who had practiced medicine for generations. The majority of female healers would qualify as folk healers, most commonly midwives, who elite physicians often criticized. Angela Ki-che Leung argues that despite this censure, women healers could earn wealth as well as "considerable social prestige" and become "respected figures in their community." Much of the criticism that elite male physicians directed towards midwives, Leung suggests, stemmed from professional jealousy, as midwives had access into homes of elite patients through childbirth assistance. Unlike in Europe and the United States, male physicians never attempted to supplant midwives as childbirth attendants. ${ }^{13}$

The treatment elite Chinese physicians offered did not involve extensive physical contact with their patients, male or female. While there were a wide variety of schools of medical thought rather than one easily defined "traditional Chinese medicine" in late imperial China, to diagnose sources of disharmony, elite healers took a pulse, looked at and listened to the patient, and assessed the case history. Touching and manipulating the patient marked a healer as lower status, focused on "outer" manifestations of a problem, rather than a deeper understanding of the "inner" issues ultimately responsible for the illness. Because of traditions of sex-segregation in China that had become

\footnotetext{
12 Noyes, $A$ Light in the Land of Sinim, pp. 85, 27-28, 29-30; W.H. Jeffreys, "A Review of Medical Education in China," China Medical Journal 23, no. 4 (July 1909): 294-99, 298.

13 According to $\mathrm{Yi}-\mathrm{li} \mathrm{Wu}$, the term in use for women physicians was yipo, which translates to "granny doctor." Chinese also used the term Nuyi, which translates to "female doctor." Angela Ki-che Leung, however, suggests that nuyi did not have the same lineage backing as yipo and were "possibly lower on the social scale." Yi-Li Wu, Reproducing Women: Metaphor, Medicine, and Childbirth in Late Imperial China (Berkeley: University of California Press, 2010), 18-19; Angela Ki-che Leung, "Women Practicing Medicine in Pre-Modern China," in Chinese Women in the Imperial Past: New Perspectives, Harriet T. Zurndorfer, ed. (Leiden, Netherlands: Brill Academic Publishers, 1999), 101-34.
} 
increasingly strict since the Song Dynasty (960-1279 C.E.), treatments that involved viewing and touching female genitals (this would include assistance in childbirth) were the exclusive domain of midwives and other female healers. ${ }^{14}$

While it is clear that women studying medicine was not in itself "an entirely new idea" for Chinese women, there were nonetheless innovative aspects of studying at the South China Medical College, many of which would have applied to Chinese men as well as women. The most obvious was the new medical techniques the school offered. Bridie Andrews has argued that the medicine Western missionaries practiced in the $19^{\text {th }}$ Century was not as dramatically different from the multitude of schools of healing available in China as either missionaries at the time or most later scholars have assumed. However, surgical techniques missionaries practiced were genuinely new to most Chinese in the $19^{\text {th }}$ Century. Surgery was part of an "outer" medicine that Chinese considered less valuable and important in China, and consequently did not fully develop. Western missionary physicians could sometimes use surgical intervention to save lives, and in a few cases perform some basic eye surgery to restore sight, especially the removal of cataracts. Removal of huge tumors also received a great deal of attention both in the United States and China. Women patients specifically benefitted from removal of ovarian cysts. Missionary physicians also introduced some innovations in the practice of gynecology that would have been especially pertinent to Chinese women practicing medicine. For example, in his report for 1880 , the year after True Light Seminary accepted female students at its medical school, Kerr discussed receiving a call to see a woman who was suffering from "retention of urine." As he recalled, he "sent one of the female pupils to relieve her, as it would be more in accordance with Chinese ideas of propriety to have a female attendant in such a case." Kerr most likely was referencing the insertion of a catheter to drain the bladder of urine. ${ }^{15}$

Beyond offering new medical techniques, Kerr's willingness to accept Chinese women as medical students offered them a chance to study medicine

14 Francesca Bray, Technologies of Gender: Fabrics of Power in Late Imperial China (Berkeley: University of California Press, 1997), 300-15; Charlotte Furth, A Flourishing Yin: Gender in China's Medical History, 960-1665 (Berkeley: University of California Press, 1999), 119-29; Wu, Reproducing Women, p. 17.

15 Andrews, Making of Chinese Medicine, 1850-1960, pp. 53-54; Ralph Croizier, Traditional Medicine in Modern China: Science, Nationalism, and the Tensions of Cultural Change (Cambridge, ma: Harvard University Press, 1968), 26-27, 37-39; Chao, Medicine and Society in Late Imperial China, pp. 157-6o; Cadbury and Jones, At the Point of a Lancet, pp. 144-55; Report of the Medical Missionary Society in China for the Year 1880 (Hong Kong: De Souza and Company, 1881), 17. 
outside the family. In transmitting knowledge of healing outside families, medical missionaries were offering an alternate way of gaining both medical knowledge and, potentially, status. Mui A-kwai was one of the first two women in Guangzhou to request medical education outside the family system. Fulton describes Mui as the first of her "helpers" in her 1915 memoir, emphasizing her importance in conducting medical work. Mui's father sold her when she was eight years old to satisfy gambling debts. Mui "never again heard from any of her family," Fulton related. "She was brought to Canton, and at eighteen sold in marriage to a Mr. How" who went to California and died there two years later. Mui then "was sent" to the True Light Seminary, where she requested admission to the Canton Medical School. While Fulton did not indicate either who sold Mui in marriage, or who sent Mui to the school after the death of her husband, her story suggests that Mui had no family support. As we have seen, Noyes indicated that women practicing medicine professionally could earn a "good income" in China, so studying medicine could provide a livelihood for a female with no family. But this same lack of family usually made it difficult for a Chinese woman to learn healing techniques. Gail Hershatter has pointed out that in late imperial and Republican China women from both wealthy and poor families "performed ... crucial and income producing labor," yet women who labored beyond their family's domestic space, "however capaciously and flexibly that space is defined ... have felt themselves and have been seen by others to be vulnerable to kidnapping ... sexual violation, and potential disgrace."16

Kerr's decision to accept females as medical students offered Mui and other women a chance to acquire the skills needed to earn money at a respectable profession, and achieve the title of "physician," while remaining in the protected space of the mission hospital. In return, the Chinese women medical students offered the Canton Hospital the chance to treat more elite women patients. Male missionaries always had been able to treat some women patients. From the time Peter Parker opened his medical work to this period in the work of the Canton Hospital, from 25 to thirty percent of the patients were women. However, most of these women patients were poor, who went to the Canton Hospital for care in part because it did not charge any fees during this period. In his 1880 report, Kerr noted that the two women medical students showed "the promise of being very useful not only in the Hospital, but in attending the better class of women in families under my direction, in cases of diseases peculiar to females." To care for the increased number of female patients, and to give the female medical students more training in obstetrics and gynecology

16 Fulton, Inasmch, pp. 54-55; Gail Hershatter, Women in China's Long Twentieth Century (Berkeley: University of California Press, 2007), $5^{1-52}$. 
work, two American women missionary physicians joined the staff of the Canton Hospital—Dr. Mary Niles in 1882 and Dr. Mary Fulton in 1884. Through the 1880 s and 1890 os, women students continued to attend the medical school at the Canton Hospital, many going on to open successful private practices. The numbers and percentages of women varied. The highest percentage during this time was nine out of twenty (45 percent) in 1890. Around 25 percent was more typical. The number of male students grew faster than the female students, so that by 1899, the year that Fulton started a separate medical school for Chinese women, five out of 35 students were female, or about 14 percent. ${ }^{17}$

Fulton began a separate medical school for Chinese women after a conflict over the direction of the Canton Hospital between Kerr and Dr. John Swan, a younger physician who had come as a medical missionary to Guangzhou in 1885. The issues involved were complex, but a main factor was that Swan advocated an adoption of newer medical standards and equipment, while Kerr viewed Swan as insufficiently committed to evangelism. Kerr left the Canton Hospital in 1899, and the thirty male medical students followed him. This left five Chinese women medical students at a school that just had experienced the decimating loss of most of its students. Swan did not make provisions for their continuing instruction. It would seem that while Swan had been willing to teach Chinese women medicine, he did not deem it worthwhile to keep a medical school open just for his female students. Swan, once called an "ardent young disciple of [Louis] Pasteur and [Robert] Koch," took the opportunity to push for a medical school with a more extensive faculty, one that would be able to better approximate the teaching of the emerging scientific medicine. This new school was not opened until 1904. ${ }^{18}$

17 Tucker, "The Canton Hospital and Medicine in Nineteenth Century China, 1835-1900," pp. 210-11, 249-51, 272; Report of the Medical Missionary Society in China for the Year 1880, p. 20; Report of the American Presbyterian Mission in Canton, 1890, 1896, 1897, Day Missions Annual Reports, Yale University Library Digital Collections, http://findit.library .yale.edu/catalog/digcoll:19333; http://findit.library.yale.edu/?f\%5Bdigital_collection_si $\mathrm{m} \% 5 \mathrm{D} \%{ }_{5} \mathrm{~B} \% 5 \mathrm{D}=$ Day+Missions+Annual+Reports\&per_page $=50 \& \mathrm{q}=\% 22$ Presbyterian + Church+in+the+U.S.A.+South+China+Mission\%22\&search_field=creator\&sort=date _dtsi+asc\%2C+sort_ssi+asc (accessed 7 August 2017); Report of the Medical Missionary Society, 1889, p. 21, Burke Library, Union Theological Seminary, New York, NY.

18 This school closed in 1914 because of Dr. John Swan's conflicts with the other physicians there. By this time, other medical schools had opened in Guangzhou with a combination of Chinese support and missionary physicians who had left the Canton Hospital because of their problems with Swan. Tucker, "The Canton Hospital and Medicine in Nineteenth Century China, 1835-190o," pp. 265-89; Cadbury and Jones, At the Point of a Lancet, pp. 103-104, 180-84; Xu, American Doctors in Canton, Chapter 2. 
During the 189os, Fulton had been saving donations from her patients to build a separate hospital for Chinese women. With these donations, combined with funds her brother, who was also a Presbyterian missionary in South China, raised during a furlough to the United States, Fulton was able to purchase land and build a combination chapel and dispensary. This enabled her to make provisions to continue the education of the female medical students, as well as accepting more women. She began a class with nine female students, using "a few maps and a skeleton," for teaching equipment, along with a few medical books which Kerr had translated into Chinese. Other donations Fulton raised in the United States enabled her to build a hospital - the David Gregg Hospital. In 1902, with the donation from E.A. Hackett, she was able to erect a substantial three-story building. In 1906, with a second donation from Hackett, Fulton constructed another building with a laboratory and lecture rooms, with the first building becoming a dormitory for the growing student body. ${ }^{19}$

A separate medical school for women was a $19^{\text {th }}$ Century Anglo-American idea, arising in the United States, Canada, and Britain. In Germany, when pressure for offering women medical education increased in the early 1900s, some proposed the "American solution" of establishing a separate medical school for women, but advocates for women's medical education rejected this proposal because of a concern that women would receive an inferior education. In 1901, when Fulton began the Hackett, more medical schools in the United States were admitting women and the percentage of women attending co-educational medical schools was rapidly increasing. ${ }^{20}$ However, having graduated from the Woman's Medical College of Pennsylvania in 1884, Fulton reflected her personal experience in the plans she developed for the Hackett, designing a separate medical school for women such as she had attended in the United States.

While one can view the idea of a separate medical school for women as an Anglo-American export, training Chinese women in Western medical techniques fit well with the growing emphasis of Chinese reformers on women's health. This concern was intertwined with broader projects of resisting imperialism. As Yi-li Wu and Tina Phillips Johnson point out, late $19^{\text {th }}$ Century reformers such as Kang Youwei and Liang Qichao "worried about the ability of the Chinese race to survive the international struggle between nations, and they saw the fate of the Chinese body politic as dependent on the health of maternal and infant bodies." Relatedly, Ruth Rogaski has shown that in the wake

\footnotetext{
19 Fulton, Inasmuch, pp. 62-65; Fulton, "Hackett Medical College for Women, Canton," pp. 324-25.

20 Thomas Bonner, To the Ends of the Earth: Women's Search for Education in Medicine (Cambridge, MA: Harvard University Press, 1992), 115.
} 
of the threats of political dismemberment from Western powers and Japan following the Boxer Uprising in 1900, Chinese elites became more concerned with adopting Western ideas of "hygiene" to achieve a strong, modern nation able to resist imperialism. ${ }^{21}$ This interest in Western medicine was particularly pronounced in Guangzhou, a city that contemporary English language sources usually referred to as "Canton." In its 1914 survey of Western medicine in China, the First Rockefeller Commission noted that

nowhere in China is there so widespread an appreciation of Western medicine as in Canton .... Even the poorly trained Chinese doctors have a lucrative practice in Canton.

In this atmosphere Chinese officials in Guangzhou came to the graduation ceremonies of the Hackett and signed the diplomas to show their support for the school. ${ }^{22}$ Having a diploma than an official had signed, or possessing any diploma at all for that matter, was not necessary for practicing medicine, but the official interest added prestige and respectability to the Hackett Medical College.

Because of the importance Chinese placed on women's health for national survival, some daughters of more elite families studied at the Hackett. Some sources describe Zhang Zhujun, one of the best known its graduates, as coming from a wealthy and prominent family. However, the majority of students entered the Hackett because they needed to practice medicine to make money. In her 1917 memoir about the True Light seminary, Noyes estimated that half the students at the Hackett had attended her school. At the same time, Noyes indicated that most students wishing to attend the Hackett did not stay for the full course that administrators offered at True Light, but rather left "as soon as they have acquired sufficient education to enable them to pass the examination required for admission to the medical college," which was an ability to read and write in Chinese. ${ }^{23}$ This suggests that acquiring the skills to practice

21 Tina Phillips Johnson and Yi-li Wu, "Maternal and Child Health in Nineteenth- to TwentyFirst Century China," in Medical Transitions in Twentieth Century China, Bridie Andrews and Mary Brown Bullock, eds. (Bloomington: Indiana University Press, 2014), 51-68; Rogaski, Hygienic Modernity, Chapter 6.

22

"Report of the China Medical Commission of the Rockefeller Foundation," p. 297, folder 242, Series 601 A, Records of the China Medical Board, Inc., Vol. II, Record Group [RG] 1, box 27, Rockefeller Archives Center, Sleepy Hollow, NY; Fulton, Inasmuch, pp. 96-98; Fulton, “Hackett Medical College for Women, Canton," p. 325.

23 For more on Zhang Zhujun in English language sources, see Xu, American Doctors in Canton, pp. $157^{-58}$. Leung casts some doubt on sources that emphasize the elite status of 
medicine, rather than a thorough education, was the priority of many Chinese who attended the Hackett.

Fulton's description of the school in a 1909 essay for the China Medical Missionary Journal explained why students could enter the Hackett without completing the full course of study at the True Light Seminary. She reported that medical instruction was "very largely practical," with students helping in hospital work and accompanying doctors who taught at the college on their outcalls. Fulton portrayed this instructional method in positive terms, suggesting that because of all the experience with patients, "by the time a student finishes she is as skillful as most doctors are in years of private practice in the homeland."24 Fulton also listed "chemistry," "anatomy," and "bacteriology" as subjects taught in the school, as well as mentioning the use of microscopes and the cultivation of bacteria. However, it is clear from Fulton's description that doctors practiced an older, apprentice-based system of education at the Hackett, one that would not have required extensive educational preparation. The Hackett thus still could provide careers for Chinese women who needed to support themselves, but did not have the funds to spend a long time in school.

One example that Fulton discusses in her memoir was Luo Xiuyun, a 1904 graduate of the Hackett. According to Fulton, Luo's family sold her as a wife at fourteen. Soon after her marriage, her husband went to the United States as a laundryman, only "occasionally" sending her money. Luo learned to read and write Chinese from her aunt, a "fine teacher of Chinese," and applied to study medicine at sixteen, eventually becoming an instructor at the Hackett. According to Luo's own recollections that she recorded in a 1926 history of the Hackett, Fulton had an active part in recruiting her to the medical school. Luo was living with another female doctor at the time, but "was not fond of medicine" and in fact would leave the room when the other doctor came home from the hospital smelling of iodoform, a strong smelling compound medical practitioners used in the early $20^{\text {th }}$ Century as an antiseptic. However, Fulton brought her to see "interesting cases" and operations, finally convincing Luo to study medicine. Luo became an instructor at the Hackett after graduation. According to Fulton, she was a skillful surgeon, performing "forty-five consecutive

Zhang's family, but does not definitively disprove them. Angela Ki-che Leung, "Dignity of the Nations, Gender, Equality, or Charity for All?: Options for the First Chinese Women Doctors," in The Dignity of Nations, Equality, Competition, and Honor in East Asian Nationalism, Sechin Y.S. Chien and John Fitzgerald, eds. (Hong Kong: Hong Kong University Press, 2006), 71-91, 85-88; Noyes, A Light in the Land of Sinim, pp. 89-90, 222-23. 
abdominal operations without the loss of a patient."25 Luo was an example of a Chinese woman who, while seemingly part of a non-traditional family with both her aunt and another woman doctor providing her with some support, needed a way to earn her own money. Since she already was married to an absentee husband, Luo could not seek support in marriage.

Fulton offered Luo, and other women like her, a new and more prestigious option for supporting themselves when they could not rely on a husband to provide for them. Yet other sources suggest that some Chinese women may have combined the practice of medicine with marriage and family. Fulton herself did not see marriage and the practice of medicine as compatible for women. In her memoir, she describes several graduates who had taught at the Hackett after graduation until marrying prominent Chinese Christian men, seeming to take it for granted that they would stop practicing medicine after marriage. "I was sorry to lose my doctors," she explains, "and I can provide for most contingencies except where men seeking wives are concerned." She in fact instituted a rule that married or engaged women could not study at the Hackett, since "in every case where engagements existed, the young man demanded the fulfillment of the girl's promise, or that of her parents, before she could complete her four years' course." The report of the First Rockefeller Commission suggests, however, that married and engaged women practiced medicine after acquiring training at the Hackett, reporting how

young women were pointed out to us in the Hackett College for Women, who were sent by their families to acquire medical training, in order that they may practice medicine as an aside to their normal domestic duties. One woman, the mother of several children, was shown us, sent by her husband to acquire this wonder-working money-making profession; and we were told that the fiancés of girls send their betrothed in advance of marriage for the same purpose.

This practice corresponds with Noyes's observations of married women in Guangzhou during the 187 os practicing medicine while raising families. While a medical school for females was a new idea in China, these women combined marriage and family with the practice of medicine. ${ }^{26}$

25 Fulton romanizes the name of this woman as "Loh." For consistency's sake, this article follows Guangqiu Xu in referring to her with pinyin romanization as "Luo Xiuyun." Fulton, Inasmuch, p. 83; Xu, American Doctors in Canton, p. 150.

26 Fulton, Inasmch, p. 94; "Report of the China Medical Commission of the Rockefeller Foundation," p. 3 . 
A 1925 catalog of the Hackett Medical College offers additional evidence of Hackett graduates continuing careers after marriage. It lists all the graduates until 1924, with an asterisk in front of married graduates. There were 76 graduates from 1903 to 1915 (this does not count women who attended but did not complete their program). Of these women, 42 had asterisks indicating marriage. As the list identified six of the women as deceased, sixty percent of those still alive in 1924 who graduated while Fulton ran the institution were married. Of the 42 married women graduates, all but five were active professionally, with the majority (29) in "private practice," one working for the Hackett Medical College, four combining private practice with work in a "school of midwifery" or a "private hospital," two working in mission hospitals, two working for a "Philanthropic Organization," and one in graduate study in the United States. ${ }^{27}$ This difference between Fulton's stated policy towards accepting married women students and the First Rockefeller Commission reports to the contrary highlights the broader question of who actually controlled the Hackett Medical School. While writing with pride in her memoir about the accomplishments of her students, Fulton consistently referred to them as "helpers" or "assistants" and portrayed herself as running the medical school and hospital. However, "most of the work done in the hospital is done by Dr. Fulton's Chinese assistants," the 1914 Rockefeller Commission reported. "She herself does very little operating now." 28 While retaining the term of "assistants," the report makes it clear that the Chinese women physicians at Hackett were in charge of the day-to-day operations at the medical school and hospital.

The husband of one of Fulton's graduates, a Dr. Fong, emphasized this same point in a more positive way in a 1915 ceremony of appreciation for Fulton. Praising Fulton for knowing how to "present her appeal effectively and unloose the purse strings of the stewards of the Lord," he also emphasized her "confidence in the people working under her." Fulton, Dr. Fong declared, "knows how to throw details on to others and she knows how to get the most from her assistants." After stating that "most of the work in the hospital was done by persons trained by" Fulton, he suggested that she "was in control, but she knew how to stay in the background so as to develop the latent capabilities of others." ${ }^{29}$ Put another way, Fong expressed appreciation for Fulton's ability to raise money

27 Hackett Medical College for Women, Turner Training School for Nurses, Canton, China, Catalogue 1925-26 (Canton: Hackett Medical College for Women and Turner Training School for Nurses, 1926), 25-27.

28 "Report of the China Medical Commission of the Rockefeller Foundation," pp. 125-26.

29 Mrs. Frank D. Gamewell, “A Notable Gathering," Mary Fulton Biographical File, Presbyterian Historical Society [hereafter PHS], Philadelphia, PA. 
and then step aside to let her former students actually run the institution, even as he called them her "assistants" and she remained nominally "in control."

Most of these Chinese women working at the Hackett were not financially dependent on Fulton or the Presbyterian Board. According to Fulton's 1909 article, only three of the fifteen women physicians on the staff of the Hackett received a salary. Fulton pointedly mentioned that medical student fees paid for these salaries, while the Presbyterian Board every year "sends us its love and regrets that it does not see its way this year to sending us any money."30 Fulton did not indicate why the other twelve worked at the Hackett for free. However, since the Rockefeller Commission report alluded to the lucrative private practices possible for medical practitioners who knew some Western methods of healing, the most likely explanation is that they supported themselves working in private practice, while helping at the Hackett. The association with the medical school would have given them more prestige and also introduced them to those needing medical attention, some of whom could become their own private patients. As much of the instruction consisted of students accompanying practicing physicians on their calls to patients, they very likely benefitted from the assistance of students, just as hospitals today depend on the labor of interns and residents. A desire to help other Chinese women gain access to medical education also could have been a motivating factor.

Since its inception, the Hackett Medical College had provided a road for upward mobility to less elite women without access to much formal education. Yet during this period, definitions of what constituted a "physician" were changing and hardening. As the new "scientific medicine" became hegemonic in the United States in the first decade of the $20^{\text {th }}$ Century, smaller, privately run medical schools began to close, and the surviving medical schools came to require much more extensive preparation and understanding of science. When the officials at the Rockefeller Foundation decided to invest in medical education in China, they were determined to bring this definition of a "physician" to China. ${ }^{31}$ In this vision, there was no room for a school such as the Hackett. Rockefeller Commission members wrote that the "work" the medical staff conducted at the Hackett was "of a low grade." Furthermore, they suggested that the training the graduates had received "hardly warrants them practicing general medicine," although they allowed that the graduates might perform a useful function "as midwives." The Rockefeller Commission also had a positive opinion about the nursing school at the Hackett, which had opened in 1909,

$30 \quad$ Fulton, "Hackett Medical College for Women, Canton," pp. 325-26.

31 Mary Brown Bullock, An American Transplant: Peking Union Medical College and the Rockefeller Foundation (Berkeley: University of California Press, 1980). 
noting how "Dr. Fulton's nurses have a good reputation among the outside doctors." Its main concern was the proliferation of medical practitioners with the title of "physician" who did not have the educational background to understand the principles of scientific medicine. This related to a broader issue confronting the Rockefeller Commission - the very popularity of some practices associated with "Western medicine" in Guangzhou meant that "Southern China ... is being flooded with a low class of practitioner."32

In 1913, Hackett and Allyn had first arrived at the Hackett, shortly before the visit of the First Rockefeller Commission to the school. Having recently graduated from prestigious medical institutions in the United States, their reactions to conditions at the Hackett were similar to that of the Rockefeller Commission. By 1915, they began to write to the Presbyterian Board outlining the problems they saw. Allyn reported to the Presbyterian Board that "Dr. Fulton herself has not kept in contact with modern medical education and did not know how far from the facts she was when she said that this school was the equal of the average medical school in America." Hackett wrote that the medical students "do not need to be able to add and subtract and many of them do not know how." She then asked in exasperation: "What kind of medical education can one give students who have had no elementary work at all?"33 In fact, graduates of the True Light Seminary, which, according to Noyes, made up about half the student body, would have known basic arithmetic, even though they did not stay for the whole course. As literacy in Chinese was the only requirement for admission into the Hackett, however, not all the students had even this much education. Yet despite lacking this knowledge at the beginning of their studies, students at the Hackett apparently were able to learn skills such as surgery and other methods of healing. Luo, for example, knew only how to read and write Chinese when she applied to the Hackett, and yet was able to learn how to perform abdominal surgery. As an apprentice-based system, the Hackett could teach skills that helped Chinese women to successful medical practices, but it could not provide the training that scientific medicine demanded.

While the educational level at the Hackett was the main focus of Hackett's and Allyn's letters, they found the power the Chinese women physicians who had been labeled as "assistants" exercised to be problematic as well. Hackett wrote that since Fulton was

32 "Report of the China Medical Commission of the Rockefeller Foundation," pp. 34-35, 44-55, 125-26, 5.

33 Harriet Allyn to Arthur Brown, 30 March 1915 and Martha Hackett to Brown, 10 May 1915, folder 4, Presbyterian Church in the UsA Board of Foreign Missions Secretaries Files: China Missions, RG 82, box 5, PHs. 
not well enough to attend to things herself ... her Chinese attended to almost everything. In fact Dr. Fulton hardly knew just what conditions were. Any missionary coming to teach had to consult the Chinese assistants. ${ }^{34}$

This confirms Fong's suggestion that Fulton's Chinese "assistants" did most of the medical work, but shows how the "control" that Fulton maintained was in name only. Hackett's letter suggests that rather than only performing the work of the hospital, the Chinese women physicians, after they had received their training at the Hackett, then made decisions at the institution. They were not amenable to simply taking Hackett's and Allyn's orders, but expected that the American women physicians would "consult" with them, implying a relationship of equals.

At the same time, Hackett's reference to the Chinese physicians as "her [Fulton's] Chinese" is revealing. Fulton resigned in 1915, citing health reasons. After Fulton's resignation, Hackett and Allyn stopped writing about their difficulties with the Chinese graduates of the Hackett who had become "assistants" in the hospital. Without Fulton's patronage, the Chinese women physicians may have lost much of their authority at the Hackett. It is possible that the Chinese women physicians left the Hackett and focused exclusively on their private practices. The 1925 catalog for the Hackett lists Luo Xiuyun's professional affiliation only as "private practice." In fact, only one Hackett graduate between 1903 and 1915 appeared on the 1925 catalog's list as having any professional affiliation with the Hackett. ${ }^{35}$ Graduates of the Hackett did not have the same kind of financial dependence on missionaries as did many Chinese women who worked in mission institutions, such as Bible women. This would have made it easier for them to leave the Hackett if they found it no longer served their needs. On the other hand, the fact that Hackett and Allyn no longer highlighted problems with the Chinese women who worked at the Hackett did not mean that the conflicts had disappeared completely. Moreover, as the medical school relied on local support, Hackett and Allyn would have needed to retain the good will of the Chinese women physicians. Like most negotiations with Chinese "assistants" in mission institutions, however, no one recorded the discussions that followed.

In subsequent letters, Hackett and Allyn emphasized that the Board needed to support the Hackett more generously if the institutions was to remain a credible medical school. In part because of the pressure of the China Medical

34 Hackett to Brown, 10 May 1915, ibid.

35 Luo Xiuyun's name appears on the list as "Loh Shan Wan." Hackett Medical College for Women, Turner Training School for Nurses, Canton, China, Catalog 1925-26, pp. 25-27. 
Board - the organization that the Rockefeller Foundation funded for its medical work in China-medical missionaries began to impose standards on mission medical schools. Hackett and Allyn were successful in raising standards over the next few years and in gaining more laboratory equipment. The increased standards may have put medical education at the Hackett out of reach for more Chinese women, but it enabled the Hackett to stay relevant in the changing medical landscape in China. At the same time, the new professions of nursing and "new style" midwifery provided opportunities for Chinese women who could no longer attend medical school. ${ }^{36}$

However, separate medical schools for Chinese women in general were much less viable in this new medical landscape. The new standards meant that it was less possible for the Hackett to operate only with American and Chinese women physicians, so it began to rely more on male physicians, both Chinese and American. Hackett and Allyn resigned in 1923, in part because of the move towards increasing the male faculty. J.A. Hoffman, a male medical missionary, took over the Hackett after their departure and held this position until 1931 when Ross Wong, a Chinese male physician, succeeded him. As Xu Guangxiu points out in his history of missionary medical work in Guangzhou, by 1932, the Hackett was "managed entirely by Chinese." Women, however, had ceased to control the institution. "All the top administrative positions," Xu writes, "were occupied by men, except for only several women accountable for nurses and nurses' education." The Hackett merged with Lingnan University in 1931, and in 1936, joined with a number of other schools to form the Sun Yat-sen Medical College. ${ }^{37}$ The Hackett was following a nationwide, and global, trend with this merger. As expensive equipment became central to medical education, medical schools had to consolidate, which meant women's medical schools combining with ones only for males. For example, in 1923, the North China Medical College for Women amalgamated with the medical school at Shandong Christian University. After the Hackett joined with other institutions, there was only one medical school for Chinese women in China-the Shanghai Christian Union Medical College for Women, which had evolved from the Southern Methodist medical school in Suzhou and opened in 1924. Most

${ }_{3} 6$ For more on the "new midwives," see Tina Phillips Johnson, Childbirth in Republican China: Delivering Modernity (Latham, MD: Rowman and Littlefield, 2011). For nursing as a new profession, see Shemo, Medical Ministries of Kang Cheng and Shi Meiyu, Chapter 5 .

37 A.J. Brown to Allyn, 21 March 1923, folder 4, RG 82, box 5, PHS; Tucker, "A Mission for Change in China," 148-52; Xu, American Doctors in Canton, p. 147; "Hackett Medical College, Report of the President, 1931" and "Hackett Medical Center Report of the Director, 1936-37," folder 4, RG 82, box 5, PHS. 
Western countries had never had separate medical schools for women. In the United States, the only remaining medical school for women by the 1920 s was the Woman's Medical College of Pennsylvania. ${ }^{38}$

Chinese women continued to have access to medical education even without separate women's medical schools. As more medical schools in Chinamissionary, government, and private- became co-educational in the 1910 s and 1920s, the percentage of "Western" or "modern" physicians who were women in China continued to rise. In some respects, co-education may have proceeded more smoothly in China than in the United States. While there were not always clear statistics, one Chinese physician undertook a survey of the proportion of male and female students in the year spanning 1932 to 1933 and published the results in the Chinese Medical Journal. At this time, there were 28 medical schools in China, with two for women (the survey counted the Hackett separately from Lingnan), two for men only, and the remaining 24 co-educational. Out of a total of 3,655 medical students in China, 619 were female, constituting 16.9 percent. In the United States at this time, there were a larger number of female medical students, but they comprised a smaller percentage of the total cohort. In the late 1920 s and early 1930s, the number of women medical students varied from around 900 to over 1,00o, but the percentage of physicians who were women, as one scholar notes, fluctuated between 4.5 and six percent until the late 1960 s. $^{39}$

In conclusion, the example of the Hackett demonstrates that terms such as "assistant" and "helper" could cover a wide range of meanings. The Chinese

38 For a firsthand account of the Woman's Christian Medical College of Shanghai, see Frances King Salmon, House of a Thousand Babies: Experiences of an American Woman Physician in China, 1922-1940 (New York: Exposition Press, 1968); Regina MorantzSanchez, Sympathy and Science: Women Physicians in American Medicine (New York: Oxford University Press, 1985), 248.

39 S.M. Tao, "Medical Education of Chinese Women," Chinese Medical Journal 47, no. 10 (October 1933), 1010-28; Morantz-Sanchez, Sympathy and Science, pp. 319, 249; Mary Roth Walsh, "Doctors Wanted: No Women Need Apply": Sexual Barriers in the Medical Profession, 1835-1975 (New Haven, CT: Yale University Press, 1977), 245, 269. In a previously published article, the author specified the proportion of Chinese women physicians as twenty percent. However, this determination relied on data in a secondary source that upon further investigation, used figures that were not reliable. Connie Shemo, "Wants Learn Cut, Finish People: American Missionary Medical Education for Chinese Women and Cultural Imperialism in the Missionary Enterprise, 1890s-1920s," Chinese Historical Review 20, no. 1 (May 2013):54-69. Readers should note as well that during this same period, women also attended the medical schools that were forming to teach "traditional" Chinese medicine. Leung, "Dignity of the Nations, Gender Equality, or Charity for All?," pp. 73, 78-79. 
women physicians at the Hackett did not depend financially on American missionaries, as did most other Chinese women who worked in missionary institutions, which may have given them more freedom to assert themselves. However, relationships of power in mission institutions were often much more complex than the official literature and published mission reports would indicate. As a rule, missionaries articulated the actual power structure of the institution only when it faced a crisis. The need to pay attention to the webs of power that could exist in mission institutions, to look beyond titles, is relevant to all scholars of mission work during this period. This point has particular ramifications for understanding how American women missionaries have contributed to ongoing imperialist discourses in the United States. While assumptions about "heathenism" as inherently evil no longer have the same resonance in popular culture, images of passive, oppressed women in non-Western cultures in need of rescue retain a hold upon the popular imagination. Arguing that the Hackett emerged in part out of traditions in Guangzhou of Chinese women healers that existed before American missionaries came to China, and exploring ways that Chinese shaped the Hackett even without formal authority, this essay questions these images. At stake is not only a more accurate conception of how the Hackett operated in its early years, or even of how ideas about women becoming physicians traveled between the United States and China. In presenting a more complex view of relationships of power at the Hackett, this essay challenges one arena in which an imperialist discourse about Chinese women continues to flourish.

\section{Selected Bibliography}

\section{Primary Sources}

Day Missions Annual Reports, Yale University Library Digital Collections, http://web .library.yale.edu/divinity/day-missions-collection-annual-reports-listing.

Fulton, Mary Hannah. "Hackett Medical College for Women, Canton." China Medical Journal 23, No. 5 (September 1909): 324-29.

Fulton, Mary Hannah. Inasmuch: Extracts from Letters, Journals, Papers, Etc. West Medford, MA: Central Committee on the United Study for Foreign Missions, 1915.

Hackett Medical College for Women, Turner Training School for Nurses, Canton, China, Catalogue 1925-26. Canton: Hackett Medical College for Women and Turner Training School for Nurses, 1925. Housed in Schlesinger Library, Harvard University, Cambridge, MA.

Jeffreys, W.H. "A Review of Medical Education in China." China Medical Journal 23, No. 4 (July 1909): 294-99. 
Mary Fulton Biographical File. Presbyterian Historical Society, Philadelphia, PA.

Noyes, Harriet Newell. History of the South China Mission of the American Presbyterian Church, 1845-1920. Shanghai: Presbyterian Press, 1927.

Noyes, Harriet Newell. A Light in the Land of Sinim - Forty Five Years in the True Light Seminary. New York and London: Fleming H. Revell Company, 1919.

Presbyterian Church in the USA Board of Foreign Missions Secretaries Files: China Missions. Presbyterian Historical Society, Philadelphia, PA.

Records of the China Medical Board, Inc, 1914-1971. Rockefeller Archives Center, Tarrytown, NY.

Report of the Medical Missionary Society in China for the Year 1880. Hong Kong: De Souza and Company, 1881.

Tao, S.M. "Medical Education of Chinese Women." Chinese Medical Journal 47, No. 10 (October 1933): 1010-28.

\section{Secondary Sources}

Andrews, Bridie. The Making of Chinese Medicine, 1850-1960. Vancouver, Canada: University of British Columbia Press, 2014.

Bonner, Thomas. To the Ends of the Earth: Women's Search for Education in Medicine. Cambridge, MA: Harvard University Press, 1992.

Bray, Francesca. Technologies of Gender: Fabrics of Power in Late Imperial China. Berkeley: University of California Press, 1997.

Buck, Peter. American Science and Modern China, 1876-1936. Cambridge, MA: Cambridge University Press, 1980.

Bullock, Mary Brown. An American Transplant: Peking Union Medical College and the Rockefeller Foundation. Berkeley: University of California Press, 1980.

Burton, Antoinette. Burdens of History: British Feminists, Indian Women, and Imperial Culture, 1865-1915. Chapel Hill: University of North Carolina Press, 1994.

Cadbury, William and Mary Hoxie Jones. At the Point of a Lancet: One Hundred Years of the Canton Hospital, 1835-1935. Shanghai: Kelly and Walsh, Limited, 1935.

Chao, Yuan-ling. Medicine and Society in Late Imperial China: A Study of Physicians in Suzhou, 1600-1850. New York: Peter Lang, 2009.

Croizier, Ralph. Traditional Medicine in Modern China: Science, Nationalism, and the Tensions of Cultural Change. Cambridge, MA: Harvard University Press, 1968.

Furth, Charlotte. A Flourishing Yin: Gender in China's Medical History, 960-1665. Berkeley: University of California Press, 1999.

Gleeson, Kristin. "Healers Abroad: Presbyterian Women Physicians in the Foreign Mission Field." Unpublished Ph.D. dissertation, Temple University, Philadelphia, PA, 1996.

Gulick, Edward V. Peter Parker and the Opening of China. Cambridge, MA: Harvard University Press, 1973. 
Hershatter, Gail. Women in China's Long Twentieth Century. Berkeley: University of California Press, 2007.

Hunter, Jane. Gospel of Gentility: American Women Missionaries in Turn-of-the-Century China. New Haven: Yale University Press, 1984.

Johnson, Tina Phillips. Childbirth in Republican China: Delivering Modernity. Latham, MD: Rowman and Littlefield, 2011.

Johnson, Tina Phillips and Yi-li Wu. "Maternal and Child Health in Nineteenth- to Twenty- First Century China." In Medical Transitions in Twentieth Century China. Bridie Andrews and Mary Brown Bullock, Eds., 51-68. Bloomington: Indiana University Press, 2014.

Leung, Angela Ki-che. "Dignity of the Nations, Gender, Equality, or Charity for All?: Options for the First Chinese Women Doctors." In The Dignity of Nations, Equality, Competition, and Honor in East Asian Nationalism. Sechin Y.S. Chien and John Fitzgerald, Eds., 71-91. Hong Kong: Hong Kong University Press, 2006.

Leung, Angela Ki-che. "Organized Medicine in Ming-Qing China: State and Private Institutions in Ming- Qing China." Late Imperial China 8, No. 1 (June 1987): 137-66.

Leung, Angela Ki-che. "Women Practicing Medicine in Pre-Modern China." In Chinese Women in the Imperial Past: New Perspectives. Harriet T. Zurndorfer, Ed., 101-34. Leiden, Netherlands: Brill Academic Publishers, 1999. 101-134.

$\mathrm{Li}$, Chuanbin. Tiaoyue techuan zhidu xia de yiniao shiye:Jidujiao zai Hua yiliao shiye yanjiu 1835-1937 [Healing Under Treaty Port Privileges: A Study of Christian Medical Work in China, 1895-1937]. Changsha: Hunan Renmin Chubanshe, 2010.

Mohanty, Chandra Talpade. "Under Western Eyes: Feminist Scholarship and Colonial Discourses." In Third World Women and the Politics of Feminism. Chandra Talpade Mohanty, Ann Russo, and Lourdes Torres, Eds., 51-78. Bloomington: Indiana University Press, 1991.

Morantz-Sanchez, Regina. Sympathy and Science: Women Physicians in American Medicine. New York: Oxford University Press, 1985.

Peng, Shumin. "Zhongguo jidujiao jindai nuzi gaodeng yixue jiaoyu de chuanli: $\mathrm{Fu}$ Mali Yisheng ji Xiage Nuzi Yixueyuan" ["The Chinese Christian Church and the Establishment of Medical Education for Modern Chinese Women: Fu Mali (Mary Fulton) and the Hackett Medical College for Women"]. In Jidujiao yu Zhongguo shehui wenhua [The Christian Church and Chinese Society and Culture]. Wu Ziming and Wu Xiaoxin, Eds., 319-54. Hong Kong: Hong Kong University Institute for the Study of Religion and the Center for the Study of Religion in Chinese Society, 2008. Pripas-Kapit, Sarah. "Piety, Professionalism, and Power: Chinese Protestant Missionary Physicians and Imperial Affiliations between Women in the Early Twentieth Century." Gender and History 27, No. 2 (August 2015): 349-73.

Pruitt, Lisa Joy. "A Looking Glass for Ladies": American Protestant Women and the Orient in the Nineteenth Century. Macon, GA: Mercer University Press, 2005. 
Robert, Dana. American Women in Mission: A Social History of Their Thought and Practice. Macon, GA: Mercer University Press, 1997.

Rogaski, Ruth. Hygienic Modernity: Meanings of Health and Disease in Treaty Port China. Berkeley: University of California Press, 2004.

Sasaki-Gayle, Motoe. "Entangled with Empire: American Women and the Creation of the 'New Woman' in China." Unpublished Ph.D. Dissertation, Johns Hopkins University, Baltimore, MD, 2008.

Scheid, Volker. Currents of Tradition in Chinese Medicine, 1626-20o6. Seattle, wA: Eastland Press, 2007.

Shemo, Connie. The Chinese Medical Ministries of Kang Cheng and Shi Meiyu: On a Cross- cultural Frontier of Gender, Race, and Nation. Bethlehem, PA: Lehigh University Press, 2011.

Shemo, Connie. "Wants Learn Cut, Finish People: American Missionary Medical Education for Chinese Women and Cultural Imperialism in the Missionary Enterprise, 189os-1920s." Chinese Historical Review 20, No. 1 (May 2013): 54-69.

Starr, Paul. The Social Transformation of American Medicine. New York: Basic Books, 1982.

Tucker, Sara. "The Canton Hospital and Medicine in Nineteenth Century China, ${ }^{1835}$ 190o." Unpublished Ph.D. dissertation, Indiana University, Bloomington, IN, 1982.

Tucker, Sara. “A Mission for Change in China: The Hackett's Women's Medical Center of Canton, China, 1900-1930." In Women's Work for Women: Missionaries and Social Change in Asia. Leslie Fleming, Ed., 137-57. Boulder, Co: Westview Press, 1985.

Walsh, Mary Roth. "Doctors Wanted: No Women Need Apply": Sexual Barriers in the Medical Profession, 1835-1975. New Haven, ст: Yale University Press, 1977.

Wong Chimin and Wu Lien-teh. History of Chinese Medicine being a Chronicle of Medical Happenings in China from Ancient Times to the Present Period. Shanghai: National Quarantine Service, 1936.

Wu, Yi-li. Reproducing Women: Metaphor, Medicine, and Childbirth in Late Imperial China. Berkeley: University of California Press, 2010.

$\mathrm{Xu}$, Guangqiu. American Doctors in Canton: Modernization in China, 1835-1935. New Brunswick, NJ: Transaction Publishers, 2011. 